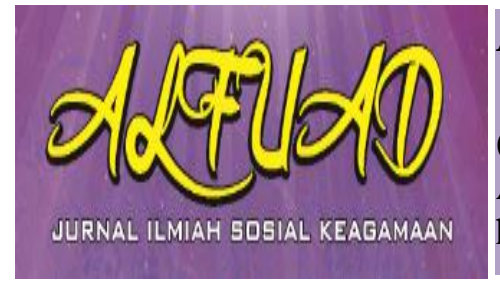

ALFUAD JOURNAL, 3 (2), 2019, (47-55)

(Print ISSN 2614-4786)

Available Online at

http://ecampus.iainbatusangkar.ac.id/ojs/index.php/alfuad

\title{
HERMENEUTIK: METODE DALAM MEMAHAMI HADIS PERSPEKTIF FAZLUR RAHMAN
}

\section{Sugianto}

Institut Agama Islam An-Nur Lampung, Indonesia.

E-mail: sugiantoalfaruqi3@gmail.com

\begin{abstract}
Understanding is a process to explore of the meaning of the teks. Understanding is different with knowing. Because, understanding imply capability to experience something be experienced by someone. Someone can be possessed of many knowledge, but little understanding. Its refer to a ability understanding someone. A variety efforts was done by ulama former, that is in order to explore meaning of the teks hadis, but that not enough. That condition, Fazlur Rahman offer a hermeneutic theory as analysis knife in operate on meaning of the texts hadis. The way in which Fazlur Rahman to understanding hadis is with hybrid between inductive and deductive system. With the result that comprehensive reading to meaning of the hadis.
\end{abstract}

Keywords: Hermeneutic, Inductive dan Deductive

\section{PENDAHULUAN}

Manusia sebagai makhluk sosial memiliki rasa ingin tahu terhadap lingkungannya. Dia selalu berupaya memahami dirinya sebagai alam mikro kosmos dan alam semesta sebagai alam makro kosmos. Dalam rangka upaya memahami realitas tersebut, manusia membuat berbagai metode yang dapat digunakan untuk memahami realitas tersebut, salah satunya adalah hermeneutik. Hermeneutik secara historis digunakan sebagai cara baca atas teks berdasarkan makna harafiahya, terdapat diberbagai bidang, seperti hukum, politik, jurnalisme, kesusastraan, dan yang paling menantang hermeneutik adalah literalisme dalam pembacaan teks-teks otoritatif, seperti misalnya kitab suci dan undangundang.

Pemahaman seperti itu di kemudian hari dalam khasanah keilmuan Islam menimbulkan kontroversi, bahwasanya metode hermeneutik tidak cocok digunakan untuk memahami alQur'an maupun hadis. Karena istilah hermeutik pada awal perkembangannya memang mulai sebagai kesibukan dengan intepretasi teks, khususnya kitab Bibel dan teks-teks filologis, namun kemudian tidak lagi membatasi diri pada metode interpretasi kitab suci, melainkan juga 
menjadi metode ilmu-ilmu sosial Umat Islam dewasa ini kemanusian dan bahkan menjadi salah memerlukan metodologis pemahaman satu dobrakan kuat dalam filsafat untuk menuangkan hadis-hadis yang ada kontemporer, khususnya epistemologi. Bersama dengan tradisi linguistic- analytic anglo-sakson, hermeneutik merupakan kontribusi Eropa kontinental untuk linguistic turn dalam filsafat kontemporer.

Dari teknik memahami makna teks, hermeneutik mempengaruhi suatu cara pandang atas manusia, masyarakat, kebudayaan dan bahkan kebenaran. Menggunakan hermeneutik lalu tidak hanya berarti mempelajari interpretasi. Karena bersangkutan dengan kemampuan yang sangat manusiawi, yaitu memahami, mempelajari hermeneutik juga berarti belajar menjadi semakin manusiawi dalam memahami yang lain dalam berlainannya, entah itu berkaitan dengan kebudayaan, agama ataupun jender. Berdasarkan latar belakang tersebut, bagaimanakah penggunaan metode tersebut jika diterapkan untuk memahami hadis?. Di antara pemahaman hadis dengan pemahaman hermeneutik adalah metode pemahaman hadis Fazlur Rahman, metode yang menawarkan pemahaman hadis dengan kajian historis-sosiologis dan kontekstual yang terkenal dengan teori ganda atau doble movment (Rahman, 1982: 7-8). dalam bentuk sunnah yang hidup, ide moral dan legal spesifik. Dalam konteks ini sunnah dipahami sebagai sebuah pedoman, dibandingkan sebagai konsep yang memiliki kandungan mutlak yang merupakan tradisi non verbal. Dengan demikian bagaimanakah metode hermeneutik dalam memahami hadis perspektif Fazlur Rahman?.

\section{HASIL DAN PEMBAHASAN}

\section{Konsep Hermeneutik}

Istilah hermeneutik bersumber dari kata hermes, yaitu seorang dewa Yunani yang mempunyai tugas sebagai pembawa pesan Jupiter di gunung Olympus kepada umat manusia. Tugas utamanya sebagai penerjemah atau interpreter terhadap pesan-pesan yang bersumber dari Jupiter ke dalam bahasa kedua yakni bahasa yang mudah difahami oleh manusia. Dalam hal ini, posisi hermes sangat urgen dan penting, sebab segala pesan harus melaluinya, konsekuensinya bahwa jika terjadi kesalahan dalam pemaknaan pesan maka dapat berakibat fatal bagi seluruh umat manusia (Sumaryono, 1993: 23-24).

Peran hermes tersebut jika dirunut secara teologis seperti peran Rasul sebagai utusan Tuhan untuk menyampaikan pesan 
dari Tuhan kepada umat manusia. Hal tersebut senada dengan kesimpulan yang telah dibuat oleh Sayyid Hussein Nasr bahwa hermes adalah representasi dari Nabi Idris A.S, yaitu manusia pertama yang telah mengetahui ilmu pengetahuan dan teknologi tenun, kesehatan, ilmu perbintangan dan ilmu yang lainnya.

Mencoba untuk keluar dari perdebatan tersebut dan mencoba mencari permasalahan inti mengenai peran hermeneutik dan metode yang digunakannya dalam menginterpretasi pesan Tuhan sebagai bahasa langit (bahasa induk) dan dilakukan interpretasi ke dalam bahasa bumi (bahasa kedua atau bahasa manusia). Berangkat dari permasalahan inilah istilah hermeneutik dapat diambil hukum universal bahwa hermeneutik merupakan sebagai seni memahami sebuah teks, sebagai metode, cara berada, menyingkap, kesepahaman, membebaskan, merenungkan dan menangguhkan.

Secara umum konsep memahami dihubungkan dengan hermeneutik karena memahami atau lebih khusus lagi memahami teks. Berbeda dalam khasanah keilmuan Islam, istilah hermeneutik satu makna dengan ilmu tafsir.

Dari konsep di atas dapat diklasifikasikan menjadi dua, yaitu hermeneutik sebagai metode dan hermeneutik sebagai filosofis. Hermenutik dipergunakan sebagai metode yang digunakan untuk memahami teks-teks Bibel, yaitu bermula dari pendekatan yang dikembangkan oleh Schleirmacher (18681834), kemudian dilanjutkan oleh Dilthey (1833-1911) yang memfokuskan pada rekonstruksi metodologis (Mahfuz, 2013: 14).

Tipe selanjutnya yaitu hermeneutik filosofis, sebagai contoh pemikiran Heidegger dan Gadamer, keduanya digolongkan ke dalam hermeneutik filosofis karena mereka tidak membahas hermeneutik sebagai metode, melainkan memikirkannya sebagai ciri ontologis, antropologis, dan epistemologis umat manusia pada umumnya. (Hardian, 2015: 22).

\section{Fazlur Rahman dan Hermeneutik}

\section{Hadis}

Fazlur Rahman lahir pada tahun 1919 yang merupakan seorang tokoh intelektual Muslim dari daerah Barat laut Pakistan. Beliau telah menyelesaikan hafalan al-Qur'an pada usia 10 tahun, mempelajari ilmu hadis dan ilmu syariah. Beliau mempunyai ayah yang memiliki pemikiran moderat dan menganjurkan untuk menyikapi dengan terbuka, karena 
hal tersebut merupakan suatu keniscayaan dan mendukung perkembangan ilmu pengetahuan baik dari ilmu tradisional maupun modern (Aminuddin, 2000: 10).

Dari lingkungan yang terbuka terhadap berbagai perkembangan terutama pemikiran dari ayahnya, Fazlur Rahman telah terbentuk karakternya melalui ayahnya. Di sini cikal bakal beliau mengembangkan konsep baru dalam memahami sebuah hadis.

Selanjutnya pendidikan Fazlur Rahman, hingga memperoleh gelar Doktor Filsafat Islam (Ph.D) di Universitas Oxford, membawanya mengembangkan karirnya sebagai dosen Studi Persia dan filsafat islam di universitas Durham dari tahun 1950 sampai 1958, hingga pada tahun yang sama ia hijrah ke Kanada diangkat sebagai lektor kepala di universitas Mc.Gill Kanada. Pada tahun 1961 ia di undang ke Pakistan oleh presiden Ayub Khan diangkat direktur Riset Islam Pakistan tahun 1961-1969, ia juga ditunjuk sebagai anggota dewan penasehat ideologi Negara Pakistan tahun 1966, hingga ia mengundurkan diri pada tahun 1969, pada tahun yang sama ia diangkat menjadi guru besar tamu di Universitas California, Los Anles dan kemudian ditarik di universitas Chicago sebagai profesor pemikiran Islam hingga
Fazlur Rahman wafat pada Juli tahun 1988 (Moosa, 2000: 35).

Dari pengalaman yang cukup lama dalam khasanah keilmuan barat kemudian beliau melihat khasanah keilmuan Islam mengalami kemandekan dalam perkembangan keilmuan Islam. Islam mengalami stagnasi intelektual yang luar biasa. Kondisi yang seperti inilah yang membuat kegelisahan akademik Fazlur Rahman.

Kegelisahan tersebut berlanjut ketika muncul reformasi atau pembaharuan Islam. Pembaharuan tersebut sebagai respon terhadap kemajuan yang telah dicapai oleh dunia modern, terutama dalam bidang iptek. Sedangkan Islam masih berkutat pada budaya teks dengan epistemologi bayani. Alih-alih mencari metode baru dalam pembaharuan bertumpu pada pendekatan yang ad hoc dan terpilah-pilah dengan mengeksploitasi prinsip takhayyur serta talfiq. Kondisi seperti ini, mendorong Fazlur Rahman untuk keluar dari mainstream yang berkembang pada saat itu, yaitu dengan cara membongkar dan mengkaji ulang terhadap ajaran Islam, serta membangun seperangkat metodologi yang sistematis dan komprehensif, khususnya yang berhubungan dengan penggalian terhadap sumber-sumber ajaran Islam. 
Kenyataan tersebut menjadi pemicu Rahman untuk mengkritisi dan menjawab tantangan pemikiran barat dengan tetap berpedoman pada tradisi tanpa harus tradisionalis (Amal, 2000: 65). Ia mengkritisi kalangan tradisionalis, kalangan fundamentalis dan kalangan modernis dan mereduksinya yang dikenal dengan neomodernisme. Konsep neomodernisme ini kemudian menjadi menu pemikiran yang ditawarkan oleh Fazlur Rahman sebagai menu pembanding kemajuan dunia barat (Majid, 1993: 24).

\section{Komponen Hadis}

Hadis jika dilihat dari struktur pembentuk hadis terdapat beberapa komponen yaitu, sanad dan matan sebagai komposisi inti dalam suatu hadis.

Sanad, akar kata dari sanat berasal dari kata dasar sanada-yasnudu, yang berarti sandaran atau tempat bersandar, tempat berpegang, yang dipercaya atau yang sah, sebab hadis itu selalu bersandar padanya dan dipegangi atas kebenarannya. Dengan demikian sanad ialah silsilah mata-rantai orang-orang yang menghubungkan kepada matan hadis.

Contoh aplikasi mata-rantai sanad:

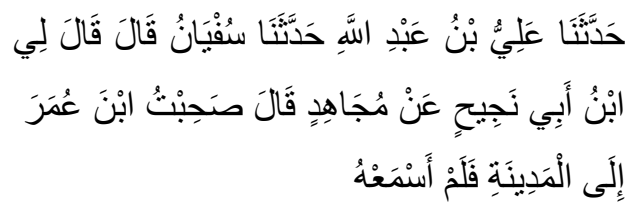

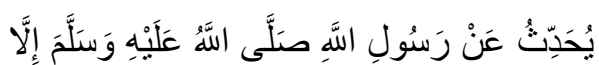

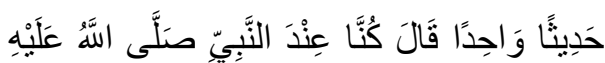

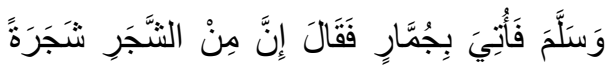

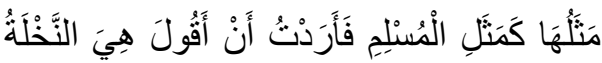

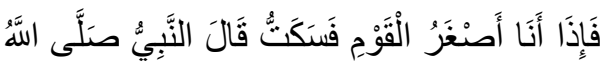

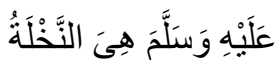

(Bukhari-70) : Telah menceritakan kepada kami Ali bin Abdullah Telah menceritakan kepada kami Sufyan berkata, telah berkata kepadaku Ibnu Abu Najih dari Mujahid berkata; aku pernah menemani Ibnu Umar pergi ke Madinah, namun aku tidak mendengar dia membicarakan tentang Rasulullah shallallahu 'alaihi wasallam kecuali satu kejadian dimana dia berkata: Kami pernah bersama Nabi shallallahu 'alaihi wasallam lalu Beliau dipertemukan dengan jama'ah. Kemudian Beliau bersabda: "Sesungguhnya diantara pohon ada suatu pohon yang merupakan perumpamaan bagi seorang Muslim". Aku ingin mengatakan bahwa itu adalah pohon kurma namun karena aku yang termuda maka aku diam. Maka kemudian Nabi shallallahu 'alaihi wasallam bersabda: "Itu adalah pohon kurma."

Hadis ini diterima oleh Bukhori melalui sanad-I, yaitu 'Ali Bin 'Abdullah, sanad ke-II sufyan, sanad keII yaitu Ibnu Abu Najih, sanad ke-IV 
yaitu mujahid, sanad terakhir yaitu Ibnu Umar. Dalam hal ini dapat dikatakan bahwa Ibnu Umar sebagai perawi pertama, mujahid sebagai perawi kedua, Ibnu Abu Najih sebagai perawi ketiga, sufyan sebagai perawi ke empat, Ali Bin Abdullah sebagai perawi kelima, sehingga sampai kepada Bukhori sebagai perawi terakhir. Dengan demikian Bukhori menjadi sanad pertama dan perawi terakhir bagi kita.

Matan, secara bahasa yaitu tanah yang tinggi, sedangkan secara istilah yaitu lafad-lafad hadis yang memiliki makna tertentu.

Dari devinisi di atas, maka matan ialah materi atau lafadz hadis itu sendiri, yang oleh penulisnya ditempatkan setelah menyebutkan sanad sebelum perawi atau mudawwin. Dengan demikian, matan hadis ialah pembicaraan atau materi yang diterima dan di-cover oleh sanad terakhir, baik isi pembicaraan itu berupa sabda Nabi saw, sahabat, maupun tabi'in, baik isi pembeicaraan berupa perbuatan Nabi saw maupun perbuatan sahabat.

\section{Hermeneutik Hadis Fazlur Rahman}

Reproduksi makna hadis harus dalam kerangka studi historis-sosiologiskontekstual sebagai metode dalam memaknai sebuah hadis. Kerangka metode inilah yang ditawarkan oleh Fazlur Rahman dalam mengungkap dan memahami sebuah teks hadis, sehingga memahami hadis tidak berkutat pada makna mantu>q akan tetapi mampu masuk ke dalam makna mafhu>.

Atas dasar kerangka tersebut, Fazlur Rahman menawarkan sebuah teori pergerakan ganda (double Movement), yang merupakan sebagai kritis atas pemahaman yang parsial terhadap hadis maupun al-Qur'an. Lebih lanjut beliau menjelaskan bahwa kecenderungan mufasir klasik dalam memahami teks hadis dengan menggunakan pendekatan tafsir bil ma'su>r sehingga hasil penafsirannya bersifat parsial dan tidak komprehensif (Rahman, 2011: 3). Dengan pendekatan tersebut, hanya mampu memotret makna hadis secara mantu> $>$, tanpa menyentuh masalah yang esensi dari pesan yang terekam dalam teks hadis tersebut. Dasar ini mendorong Fazlur Rahman untuk menawarkan metode baru dalam memahami sebuah hadis, yang dengan metode tersebut mampu menjangkau lebih luas, tidak hanya sekedar menggunakan analogy atau teori qiyas tradisional. (Sumantri, 2013: 6).

Selanjutnya beliau menawarkan teori dan pendekatan yang digunakan 
untuk memahami hadis. Adapun teori yang digunakan yaitu teori double movements, teori ini menawarkan bahwa untuk memahami makna dan pengertian sebuah hadis haruslah dengan mempelajari situasi dan masalah-masalah yang dihadapi atau yang menjadi latar belakang hadis. Oleh karena itu memahami masyarakat, agama, kebudayaan dan institusi-institusi ketika ayat al-Qur'an diturunkan menjadi keharusan (Rahman, 1986: 6).

Untuk mengaplikasikan konsep tersebut, maka perlu diupayakan reinterpretasi terhadap teks keagamaan. Fazlur Rahman membedakan hermeneutik keagamaan dengan teorinya double movements ke dalam dua gerakan, yaitu:

Gerakan pertama: gerakan ini dibagi ke dalam dua cara, pertama memahami hadis sebagai jawaban atas situasi atau permasalahan historis (yang lebih dikenal dengan istilah asbab al$w u r u>d$ ). ke-dua, melakukan inferensi terhadap kemungkinan-kemungkinan jawaban yang spesifik tersebut dan menyatakannya sebagai pernyataanpernyataan yang memiliki tujuan-tujuan moral-sosial umum yang dapat disaring dari teks-teks spesifik dalam perspektif latar belakang sosio-historis dan rasionallogis (Rahman, 1984: 7).
Adapun langkah selanjutnya yaitu harus melakukan pola berfikir deduktif yang harus dirumuskan dan direalisasikan sekarang. Yaitu, ajaran-ajaran yang bersifat umum harus di-qiyas-kan dalam konteks sosio-historis yang konkrit di masa sekarang.

Dari paparan di atas dapat dipahami bahwa langkah pertama yang ditempuh Fazlur Rahman yaitu dengan menggunakan metode berfikir induksi dan langkah kedua dengan menggunakan metode berfikir deduksi. Keunggulan metode ini yaitu, penekanan pada kebutuhan untuk memahami al-Qur'an dan hadis dalam kesatuan secara keseluruhan, kedua: dapat membedakan antara hukum umum dan khusus, ketiga: pemahaman latar belakang dan konteks historis untuk memahami al-Qur'an dan hadis. Dengan demikian akan ditemukan nilai normatif atau substansial dari suatu teks atau naskah. Metode yang dikembangkan Fazlur Rahman jika di telusuri lebih dalam mirip dengan metode yang dikembangkan oleh Creswell dalam metode penelitian campuran (mixed methods) (Creswell, 2009: 203).

Sedangkan pendekatan yang beliau tawarkan yaitu pendekatan historis atau pendekatan sosiologis (Rahman, 1984: 330). Pendekatan ini sering disebut juga 
dengan pendekatan induktif atau integratif kemudian digabungkan dengan pendekatan deduktif, langkah tersebut dapat dibuat sebuah pendekatan hibrid dalam memahami sebuah naskah.

Agenda utama Fazlur Rahman dengan metode tersebut yaitu dalam rangka evolusi hadis menjadi sunah yang hidup saat ini. Di sini peran akal dalam mengaktualisasikan makna hadis menjadi sangat penting. Sehingga muncul dialog antara akal dengan teks suci yakni hadis.

Kondisi semacam perdebatan antara akal dan wahyu sudah berlangsung lama dalam khasanah keilmuan Islam. Puncaknya pada abad pertengahan penaklukan nalar manusia di bawah otoritas wahyu. Sehingga muncul fenomena taqlid buta dimana penggunaan nalar ijtihad diharamkan. Berbeda dengan era modern, posisi nalar teramat sentral dan istimewa melampaui pembenaran dan bahkan pemutlakan nilai-nilai agama. Secara konseptual, metode yang dikembangkan oleh Fazlur Rahman dalam rangka mempertemukan antara peran akal dan wahyu. Wahyu sebagai tuntunan ilahi diturunkan tak lain untuk membimbing entitas akal menuju jalan yang benar sesuai rambu-rambu Tuhan. Sebaliknya, akal pikiran diciptakan Tuhan menjadi mi'yar dalam menentukan baik-buruk, suci-najis, dan maslahah mafsadah. Setidaknya pandangan seperti ini mengacu pada filsafat hukum islam yang mendasarkan bahwa wahyu Tuhan turun tak lain untuk mendatangkan kemaslahatan dan menentang terjadinya kerusakan (jalb al-masha>lih wa dar almafa $>$ sid).

\section{KESIMPULAN}

Berdasarkan paparan di atas dapat disimpulkan bahwa hermenutik yang dikembangkan Fazlur Rahman mengadopsi hermeneutik yang dikembangkan oleh Dilthey, yaitu dalam memahami sebuah teks hadis harus mengacu pada aspek historis, aspek sosiologis, dan aspek antropologis masyarakat. Sedangkan metode yang ditawarkan oleh Fazlur Rahman yaitu menggabungkan pola berfikir induktif dan pola berfikir deduktif dalam memahami makna teks hadis. Jadi pembacaan yang komprehensif yaitu menggabungkan antara metode istiqroiyah dan istidlalliyah dalam mengungkap sebuah makna.

\section{DAFTAR PUSTAKA}

Ahmala. (2013). Hermeneutik: Mengurai Kebuntuan Metode Ilmu-ilmu Sosial, dalam edi Mulyono, dkk, Belajar Hermenuitik dari konfigurasi Filosofis mеnuju 
Praksis studi islam. Yogyakarta: IRCiSoD.

Al-Khatab., Al-Ajaj., \& Muhammad (1981). Ushul al-hadist, 'Uulumu wa mushthalahuhu. Beirut: Dar alFikr.

Aminuddin, M. H. (2000). Konsep Negara Islam menurut Fazlurrahman. Yogyakarta: UII Press.

Askan, H. C. (1989). Bultmann, Rudolf Karl. dalam: Christel Dehlinger et.al. (ed), Metzler Philosophen Lexikon. Stuttgart: JB. Metzlersche Verlagbuchhandlung,.

Bollnow, O. F. (1958). Die Lebensphilosophie. Berlin: Springer Verlag.

Creswell, J. W. (2009). Research Design: qualitative, quantitative, and mixed methods approaches. London: Sage Publications.

Davey, N. (2006). Unquiet Understanding, Gadamer's Philosophical Hermeneutics. New York: State University of New York Press.

Grondin, J. (2000). Einfuhrung $Z u$ Gadamer. Tubingen: Mohr Siebeck.

Hardian, F. B. (2015). Seni memahami: Hermeneutik dari Scheleirmacher sampai Derida, Yogyakarta: Kanisius.

Lafont, C. (2005). Hermeneutic. dalam Hubert L. Dreyfus et.al. (ed), A companion to Heidegger. Oxford: Blackwell.

Mahfudz, M. (2013). Hermeneutika: Pendekatan Alternatif dalam Pembacaan Teks. Al-fFkr, 17 (2).

Majid, N. (1993) Fazlur Rahman dan Rekontruksi Etika al-Qur'an. Jurnal Islamika, 2.

Moosa, E. (2000). Introduction. dalam Fazlur Rahman, Revival and Reform in Islam: A Study of Islamic Fundamentalism. Oxford: One World Publication.
Rahman, F. (1982). Islam and Modernity. Chicago and London: University of Chicago Press.

Sumantri, R. A. (2013). Hermeneutika alQur'an Fazlur Rahman: Metode Tafsir Double Movment. Jurnal Komunika, 7 (1).

Sumaryono, E. (1993). Hermeneuitik (sebuah Metode Filsafat), Yogyakaarta: Penerbit Kanisius.

Syamruddin. (2011). Hermeneutika Fazlur Rahman, Upaya Membangun Harmoni Teologi, Etika dan Hukum. Jurnal Miqot, 30 (2). 